http://kitaibelia.unideb.hu/

ISSN 2064-4507 (Online) • ISSN 1219-9672 (Print)

(C) Department of Botany, University of Debrecen, Hungary

22 (2): 286-296.; 2017

DOI: $10.17542 /$ kit.22.286

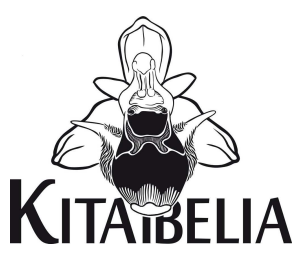

\title{
Két új adventív faj előfordulása Magyarországon a buzérfélék (Rubiaceae) családjából
}

\author{
BAlOGH Lajos ${ }^{1} \&$ MesterházY Attila ${ }^{2}$ \\ (1) Savaria Megyei Hatókörű Városi Múzeum, Természettudományi Osztály, H-9701 Szombathely, Kisfaludy Sándor u. 9. \\ balogh.lajos@savariamuseum.hu \\ (2) Hortobágyi Nemzeti Park Igazgatóság, H-4024 Debrecen, Sumen utca 2.; amesterhazy@gmail.com
}

\section{Two new adventive species from the Rubiaceae family in Hungary}

Abstract - Two alien species from the Rubiaceae family were recorded as new for Hungary in 2016. Phuopsis stylosa is a rarely used garden plant in Europe, originally occurs in south-west Asia. A small escaped and established stand was found in Csákánydoroszló village in Vas County (West Hungary). Also a small group of Galium murale was discovered in Budapest-Keleti Railway Station (Central Hungary). This species is originated from the Mediterranean and probably spreads by rail transport. Both species are represented in their habitats by small populations therefore their invasiveness can only be evaluated after several years' monitoring.

Keywords: Galium murale, Hungary, neophyte species, Phuopsis stylosa, Rubiaceae

Összefoglalás - A szerzők két, korábban Magyarországról nem ismert, a Rubiaceae családhoz tartozó faj első adatát közlik. A Délnyugat-Ázsiából származó, dísznövényként Európában szórványosan ültetett piros szálkanyak (Phuopsis stylosa) a Vas megyei Csákánydoroszló község közúti árkának degradált mezofil gyepjében telepedett meg. A Mediterráneumban őshonos kőfali galaj (Galium murale) kis állománya a budapesti Keleti pályaudvar egyik használaton kívülimellékvágánya mentén került elő. Előbbi faj feltételezhetően ültetésből vadulhatott ki, míg utóbbi jelenléte a vasúti forgalomnak köszönhető. Mindkét faj egyelőre csak kis egyedszámban van jelen élőhelyén, így inváziós képességük csak több éves megfigyelést követően értékelhető. A fajok beillesztésre kerültek a hazai határozókulcsba.

Kulcsszavak: buzérfélék, Galium murale, Magyarország, Phuopsis stylosa, újjövevény növényfajok

\section{Bevezetés}

A Rubiaceae családot hazánkban 5 nemzetség mintegy 37 faja képviseli (VIDÉKI 2009), ezek közül viszonylag kevés adventív fajt ismerünk. Ebbe a kategóriába sorolható az egykor Szegedről közölt Galium humifusum M. Bieb., valamint a korábban dísznövényként termesztett Asperula orientalis Boiss. et Hohen. Mindkét faj csak ideiglenesen telepedett meg Magyarországon (Soó 1966, VIDÉKI 2009).

2016. május 15-én, „az Őrség kapujában”, a Vas megyei Csákánydoroszló falu főutcája alatt átfolyó vizesárok rézsűjében Balogh Lajos egy rózsaszínen virágzó (dísz)növény elvadult állományára bukkant, amely a hazai kézikönyvekben eddig nem szereplő, a magyar flórából még nem közölt piros szálkanyaknak (Phuopsis stylosa (Trin.) Hook.f. ex B.D. Jacks.) bizonyult. 
2016. május 27-én, Budapesten, a Keleti pályaudvar egyik mellékvágányának gyomos szegélyében pedig Mesterházy Attila találta meg az Európában terjedőben lévő, de korábban hazánkból nem ismert kőfali galajt (Galium murale (L.) All.).

\section{Anyag és módszer}

A közleményben említett taxonok tudományos neveinek használata KIRÁLY (2009) határozókönyvét, a társulásfelvételezés pedig a Zürich-Montpellier-iskola módosított módszerét követi, a dominancia-értékek \%-os megadásával (JAKUCS 1981). A herbáriumi adatgyújtés az alábbi intézményeket érintette (rövidítésjel az Index Herbariorum-ban, THIERS 2017): Debreceni Egyetem, Debrecen (DE); Eszterházy Károly Egyetem, Eger (EGR); Kaposvári Egyetem, Kaposvár; Magyar Természettudományi Múzeum Növénytár, Budapest (BP); MTM Bakonyi Természettudományi Múzeuma, Zirc; Savaria Múzeum, Szombathely (SAMU); Szent István Egyetem, Budapest. A Phuopsis stylosa bizonyító példányai a BP és SAMU, a Galium murale esetében pedig a BP herbáriumba kerültek.

\section{Rendszertani besorolás, nevezéktan}

A buzérfélék családjába (Rubiaceae) tartozó Phuopsis (Griseb.) Hook.f. alaktani, molekuláris és kariológiai jegyeit tekintve a Crucianella L. és az Asperula L. között álló, monotipikus nemzetség (LINCSEVSZKIJ 1961, NATALI et al. 1996, WEISS-SCHNEEWEISS \& SCHNEEWEISS 2003). A fajt eredetileg a szoros rokonságban álló Crucianella genusban írták le, később további Rubiaceaenemzetségekbe sorolták, míg az utóbbi évtizedekben elfogadott neve Phuopsis stylosa (Trin.) Hook.f. ex B.D. Jacks. 1894. További szinonimjai (RBG 2016): Asperula ciliaris DC. 1830, Asperula stylosa (Trin.) Boiss. 1843, Crucianella stylosa Trin. 1818, Galium stylosum (Trin.) E.H.L. Krause 1904, Laxmannia fasciculata Trin. 1818, Nemostylis ciliaris (DC.) Steven 1857.

(A Crucianella fajok a Mediterráneum és Nyugat-Ázsia nyílt, száraz élőhelyein honos lágyszárúak vagy félcserjék (BORBÁs 1893, EHRENDORFER 1976). A „kis magyar flórából” nem ismertek, a Kárpát-medencében őshonosan a Nyugat-Mediterráneumban jellemző keskenylevelű v. ösztörűs szálkanyak (Cr. angustifola L.) subsp. oxyloba Janka alfaja él az Aldunánál, illetve a Kelet-Balkánon és a Krímen át tovább kelet felé (JÁvoRKA 1924-1925). A szintén déleurópai elterjedésű széleslevelű szálkanyakat (Cr. latifolia L.) PRIsZTer (1985) régi adventív adatként jelzi hazánkból.)

Mivel a hazai flórára nézve új növénynemzetségről van szó, a Phuopsis esetében annak néveredetéről is szólunk. Tudományos nemzetségneve a görög phu (egy macskagyökér-féle) és opsis (hasonlító) szavakból származik, utalva a Valeriana phu-val, illetve a mindkét növényből áradó kellemetlen illatanyagot illetően érzékelhető hasonlóságukra. A faji név, stylosa, a virágból feltűnően kiálló bibeszálakra utal (MBG 2017). A növény magyar neve megőrizte a kezdeti nemzetség-besorolást (PRISZTER 1998). A szálkanyak alighanem DiószEGI \& FAZEKAS (1807) névalkotása, míg BoRBás (1893) a Crucianella-ra a talán tőle való keresztlomb nevet is említi.

A szintén buzérfélékhez (Rubiaceae) tartozó galajok (Galium) a család Európában legnépesebb nemzetsége (EHRENDORFER et al. 1976). A Galium murale (L.) All. 1785-t a nemzetség Kolgyda Dumort. (syn. Aparine Koch) szekciójába sorolják, amelybe egyéves, kevés virágú levélhónalji virágzatokkal rendelkező fajok tartoznak. A hazánkban előforduló fajok közül ide sorolhatók a következők: G. spurium L., G. tricornutum Dandy, G. aparine L., G. divaricatum Pourr. ex Lam., G. tenuissimum M. Bieb., G. parisiense L.. Ezek közül a G. parisiense az, amely a G. murale-hez hasonlóan Dél-Európából hurcolódhatott be a Kárpát-medencébe. Míg azonban az előző faj terjedését a korábban nagy létszámú legelő állatok vándoroltatása segíthette elő, addig utóbbi behurcolása valószínűleg a vasúti közlekedésnek köszönhető. 


\section{Alaktani jellemzők}

A Phuopsis stylosa 20-30(-50) cm-es termetű, gyepes, kúszó növekedésű, finoman molyhos, lágyszárú évelő (hemikriptofiton). Szára élesen négyszögletű, az éleken lehajló tüskeszőröktől érdes. Halványzöld vagy szürkés, ár alakú, szúrós levelei örvökben állnak, szélük érdes, lefelé görbülő. Apró, ötcimpájúan csöves, rózsaszín virágai kerekded fejecskét alkotnak. Aromatikus növény, virágzása hosszan, májustól augusztusig tart, virágai meleg időben olykor pézsmaillatúak. A faj 'Purpurea' (syn. 'Rubra') kertészeti változatának virágai bíborvörösek (Silva Tarouca \& Schneider 1922, Macoboy 1988, Brickell 1993, Parker \& Malone 2006).

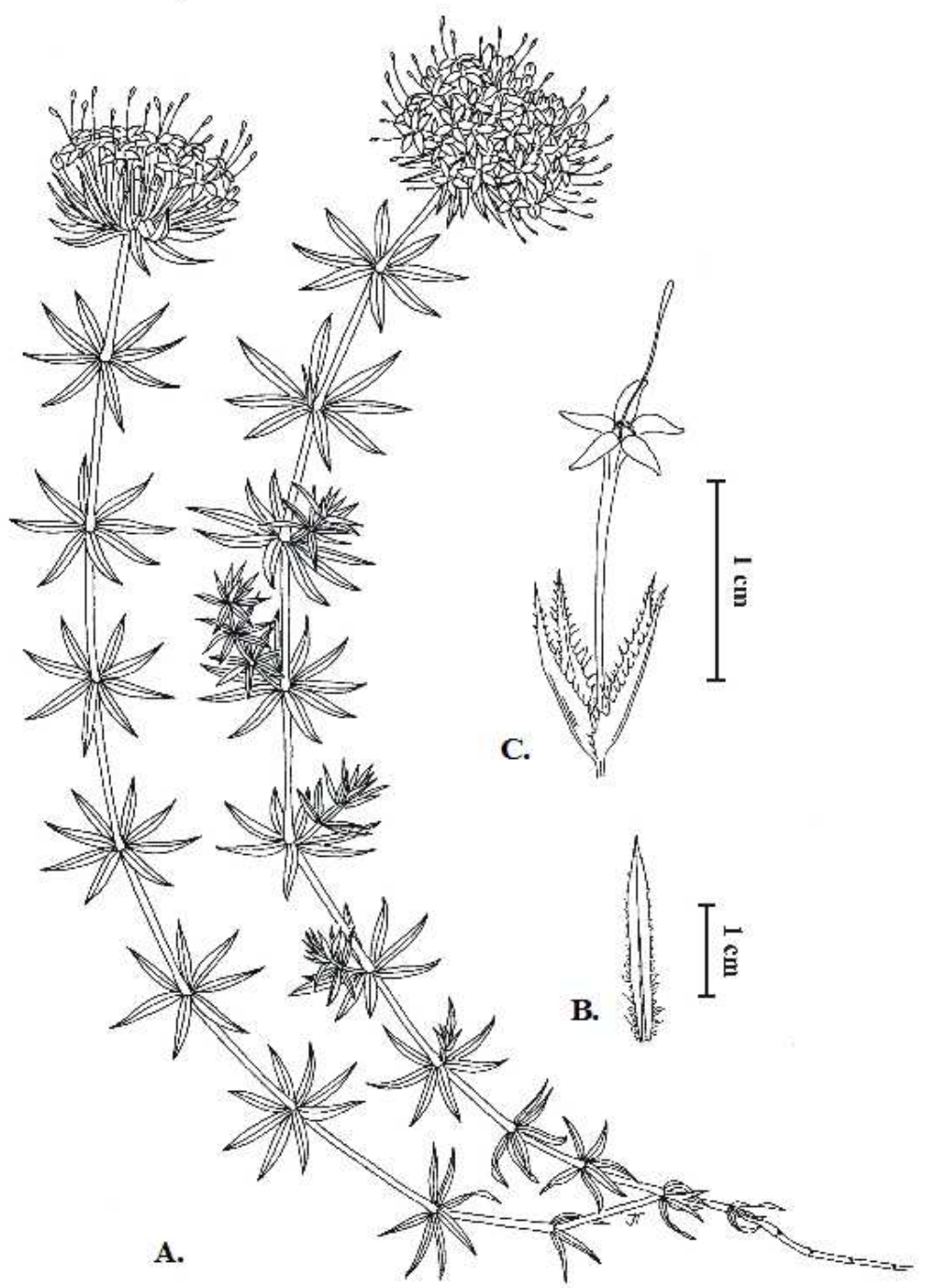

1. ábra. Phuopsis stylosa (Jana Táborská rajza) A: habitus, B: levél, C: virág Fig. 1. Phuopsis stylosa (Drawing by Jana Táborská) A: habit, B: leaf, C: flower 
A Galium murale egyéves, egyszerű szőrös növény, általában elterülő, kisebb csomókban nő. Szára vékony, 1,5-30 cm hosszú. Levele lándzsás vagy szálas-lándzsás, 1-8 mm hosszú, 1 mm széles, csúcsa szálkahegyben végződik. A levél szélén a levél csúcsa felé irányuló szőrök találhatók. A levélörvök (3) 4-6 levélből állnak. A párta sárga, csöve jelentéktelen, a csészéből nem lóg ki, cimpái oldalra elállók. A csésze szőrös, a merev szőrök vége horgas. A virágok magánosak vagy 2-4 virág alkot egy álernyőt. A virágok kocsányai $0,5-1,5 \mathrm{~mm}$ hosszúak, rövidebbek, mint a murvák, virágzás után lehajlók. Termése hengeres, 1,5-2 mm hosszú, horgas szőrökkel borított (EHRENDORFER et al. 1976). A hazánkban előforduló galajok közül leginkább az egyéves apró fajokkal lehet összekeverni (G. tenuissimum, G. divaricatum, G. parisiense), utóbbiak azonban felálló szárú, hosszabb (2-15 mm) virágkocsányú fajok.

C.

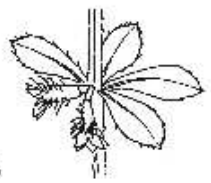

B.

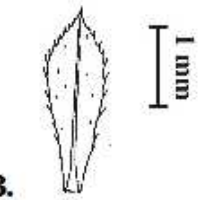

D.

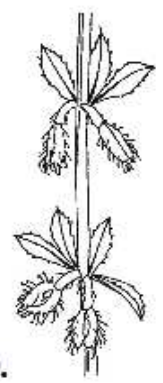

F.

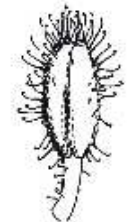

\section{$\overrightarrow{\mathrm{E}}$}

E.
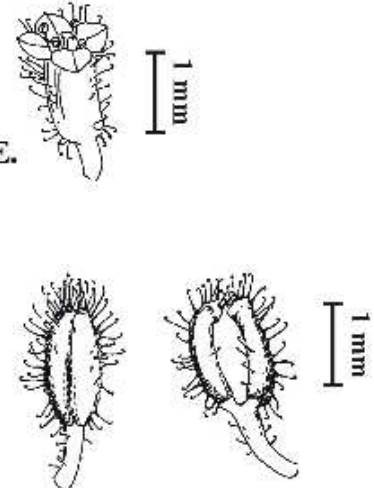

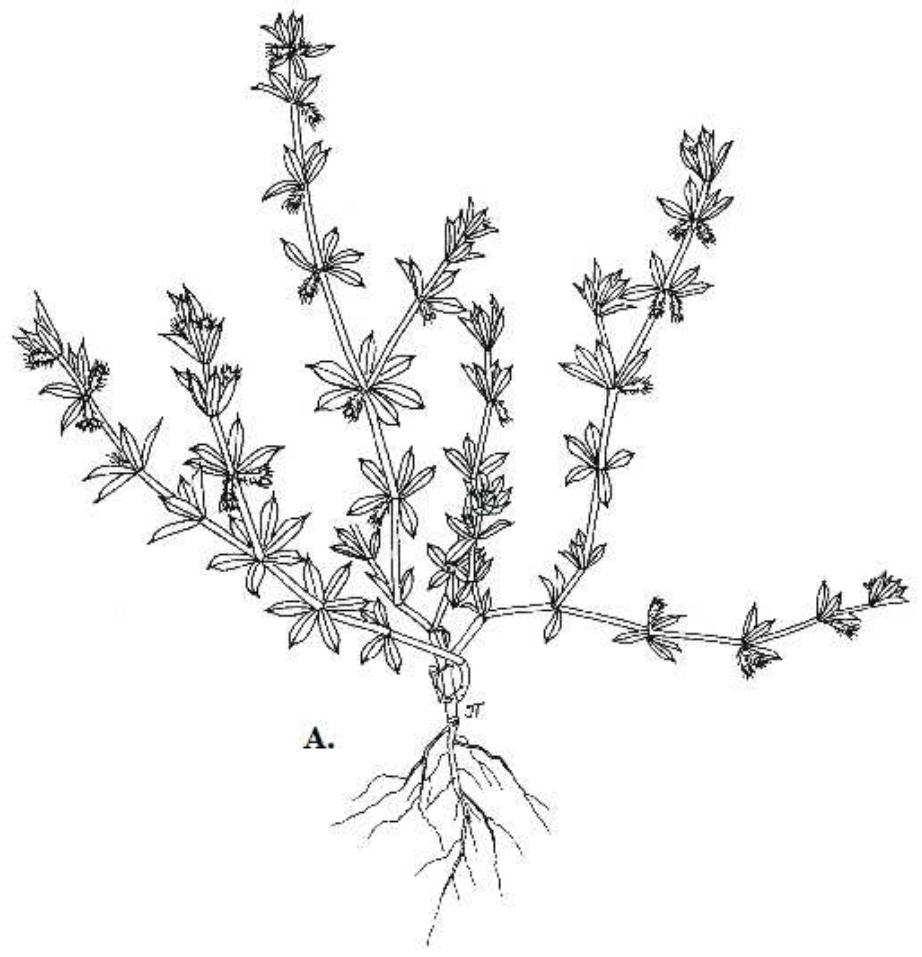

2. ábra. Galium murale (Jana Táborská rajza)

A: habitus, B: levél, C: levélörv virágzattal, D: levélörv terméssel, E: virág, F: termés

Fig. 2. Galium murale (Drawing by Jana Táborská)

A: habit, B: leaf, C: leafwhorl with inflorescence, D: leafwhorl with fruits, E: flower, F: fruit 
A Ph. stylosa és a G. murale magyar nyelvű szakirodalomban eddig nem lelt ábrázolását ezúton közöljük (1. és 2.ábra).

A két, újonnan megtalált faj beillesztését a hazai határozókulcsba (VIDÉKI 2009) a következőképp javasoljuk:

1a A párta 5 tagú. 2

1b A párta 4 tagú, a bibe rövidebb, a pártából nem lóg ki (Sherardia, Asperula, Galium, Cruciata)

2a A bibe hosszú, a pártából hosszan kilóg, a száraz termés 1,5 $\mathrm{mm}$ hosszú Phuopsis

2b A bibe nem lóg ki hosszan a pártából, a termés 5-7 mm, húsos, fekete bogyó $\quad$ Rubia

\section{Phuopsis (Griseb.) Hook. f. - Szálkanyak}

Kúszó gyöktörzsű, heverő szárú, lágyszárú évelő. A szár négyszögletű, az éleken lehajló, merev szőröktől érdes. A levelek 6-10 tagú örvökben állnak, ülők, lándzsásak, 1-2(-2,5) cm hosszúak, (2-)3-5 mm szélesek, szúrós hegyűek, halványzöldek, szélük érdes, lefelé görbülő. A párta 12-15 mm hosszú, rózsaszínű, 5 cimpájú, a bibe hosszan kinyúló. A virágok szártetőző fejecskébe tömörülnek. A résztermések 1,5 mm hosszúak. H: 20-30(-50) cm. He. V-VIII. Adv. (DNy-Ázsia). Dísznövény, kivadul. Kaszált gyepben. NyDt (Csákánydoroszló). [Crucianella stylosa Trin.]

Ph. stylosa (Trin.) Hook. f. ex B.D. Jacks. - Piros sz.

\section{Galium L. - Galaj}

$\cdots$

18a A szár t-k. heverő, tövén 1-2 mm Ø, a levelek $1(-2) \mathrm{cm}$ hosszúak. - A pártacimpák hegyesek, de nem fonalas csúcsúak..........................................................................................19

18b A szár felálló, tövén vastagabb 2 mm-nél, a levelek rendesen hosszabbak......................21

19a Egyéves növény. A levél elszórtan szőrös, széle nem visszagöngyölődő. A virágok 2-4 virágú levélhónalji álernyőben állnak. A párta sárga. - A levél lándzsás v. széles lándzsás, 1-8 mm hosszú, $1 \mathrm{~mm}$ széles. A termés hengeres, horgas szőrökkel borított, a résztermés 1,3-1,5 mm Ø. T: 5-20 cm. Th. IV-VII. Adv. (Med.-Ny-Ázsia). Bolygatott, köves helyek. NA (Budapest) igen ritka.

G. murale (L.) All. - Kőfali g.

19b Évelő növény. A virágok végálló bugát alkotnak. A párta fehér. A levél kopasz, széle begöngyölt. .20

\section{Eredeti és adventív elterjedés}

A Phuopsis stylosa délnyugat-ázsiai faj, amely a Kaukázus déli területeitől Irán északnyugati térségéig fordul elő (Irán Gilán tartományából írták le) (LINCSEVSZKIJ 1961).

Jövevényfajként kontinensünkről eddig viszonylag kevés országból jelezték, az európai flóramű még nem tartalmazza (TuTiN et al. 1976). A földrészünkön talán leggazdagabb adventív-flórával bíró Brit-szigetek déli és nyugati térségeiben megtelepedett kerti szökevényként már régebbtől számos előfordulását ismerték, meghonosodottnak 1927-től tekintik Wales (St. Donat's, Glamorgan) mészkőpartjain (CLEMENT \& FosTER 1994). Ausztriában Stájerország tartományi székhelyéről, a Graz feletti Schlossberg délnyugati oldalából jelezték nem 
állandósult elvadulását (KRAŠAN 1891; HAMBURGER 1948 és JANCHEN 1956-60 nyomán WALTER et al. 2002). Innét származó, 1884. május 27 -én, E. Preissmann által gyújtött példánya (J. Bubela, majd Flatt Károly gyűjteményéből) ismertes a Debreceni Egyetem herbáriumából (DE). A Kárpát-medence országaiból további szubspontán előfordulásairól nem tudunk. Az e térségből származó, magyarországi herbáriumokból (BP, SAMU) ismert példányok mindegyike termesztésből való, melyek időrendben az alábbiak:

Crucianella stilosa, szálkanyak, Von aus Pest erhaltenen Samen in Garten cultivirt, Juni-Aug., Poljana Jaszinya [Kőrösmező, Kárpátalja, Ukrajna], [1]845. Aug., L. Vágner. = Phuopsis stylosa (Trin.) Benth. et Hook. f., rev.: Ehrendorfer, 1950 (BP-HA: 213358).

Cr. stylosa Trin., Persia bor., C. in h. b. Vienna [Bécs, Ausztria], Herbarium Archiepiscopi Dris Ludovici Haynald, 3102 (BP-HG: 365386).

Cr. stylosa Trin., Bot. Garten, [leg.] ...?..., E herbario Frid. Hazslinskyi (BP-HG: 365387).

Cr. stylosa Trin., Langgriffallige Kreuzpflanze, Naturland: Persiens, Zu Preßburg [Pozsony, Szlovákia] in Gärten, [leg.] Schneller. = Ph. stylosa (Trin.) Benth. et Hook. f., rev.: Ehrendorfer, 1950 (BP-HA: 213357).

Cr. stylosa Trin., cult., Güns [Kőszeg], 1897.VI.29., [leg. et det.] Piers major, ...?... (SAMU).

Cr. stylosa Trinius, Gestielter Kreuzling, Kőszeg, 1912.VII.23., [leg. et det.: Piers Vilmos] (SAMU).

Cr. stylosa Trin., Ex hort. cult. in „Iglauer-arboretum”, Városlőd, comit. Veszprém, 23. VI. 1953., Papp József, Patria: Oriens, Herb. J. Papp, Budapest, 3447/. (BP-HA: 374996).

Cr. stylosa, [Vácrátóti bot. kert?], Herbarium of Imre Máthé Sr., BP, 2012 (BP-HA: 729906).

(Rövidítések: BP-HA = MTM Növénytár /Budapest/: Herbarium Adventivum; BP-HG = MTM Növénytár: Herbarium Generale; SAMU = Savaria Múzeum /Szombathely/)

A Galium murale őshonos areájának központja a Földközi-tenger medencéje, ahonnét délre az Arab-félsziget mentén egészen Szomáliáig, míg keletre Iránig húzódik. Feltételezhetően az Azori- és Kanári-szigeteken, valamint a Madeirán lévő populációk is a faj eredeti elterjedési területéhez tartoznak (WPF 2016).

Adventívként megjelent az Újvilág mediterrán régióiban (Argentína, Chile, Kalifornia egyes területei), valamint Ausztrália déli részén és Új-Zélandon. Európában a Mediterrán régión kívül eddig csak négy országból jelezték előfordulását. Belgiumban a faj első említése 1902-ből származik, a Vesdre folyó völgyéből. Később néhány kisebb, időszakos megjelenését észlelték, melyeket a Mediterráneumból származó dísznövényimporttal hoztak összefüggésbe (HosTE et al. 2009). 2014-ben Gent utcáinak járdaszegélyében, valamint falak tövében találtak két előfordulását, majd 2016-ban jelentős állománya került elő több tengerparti kemping környékéről. Utóbbi előfordulások ráirányítják a figyelmet a turizmus idegenhonos növények terjesztésében játszott komoly szerepére (VERLOOVE 2016). Hollandiából 1970-es években derült fény időszakos megtelepedésére (ADEMA 1974). Angliában az 1900-as évek elejétől kezdődően időszakos megtelepedései ismertek Sussex megye keleti részéből, többnyire dísznövény-kertészetek környékéről (CLEMENT \& FosTeR 1994, STACE 2010). Csehországban 2009-ben találták a prágai Károly Egyetem kampuszának bejáratánál, kis példányszámban (PrANČL 2012). A Kárpát-medencéből nem ismertek a faj előfordulásai, illetve korábbi gyűjtései. Őshonos elterjedési területén kívüli kisszámú európai előfordulásai döntően alkalmiak, élőhelyein nem számít agresszívan terjedő fajnak. Egyedül Belgiumban figyelték meg lokális invázióját (VERLOOVE 2016). 


\section{Magyarországi előfordulás}

A Phuopsis stylosa 2-3 m²-es, virágzó állománya 2016. május 15-én, a Vas megyei Csákánydoroszló községben, a Vasút utca keleti oldalán, a temető előtti parkoló mentén mintegy 10 $\mathrm{m}$ hosszan húzódó virágdomb déli végének folytatásában, a közút alatt átfolyó vizesárok rézsủjében, géppel kaszált gyepben került elő (koord.: N 46.97255, E $16.50483^{\circ}$ ) (3. ábra). A falu polgármesterének BALOGH \& MESTERHÁZY (2017)-hez képest újabb keletű tájékoztatása szerint a virágdomb telepítésekor a növényt nem ültették. A Google 2012 februárjában készült felvételén már a virágdomb déli végében látható mészkőtömböket egy vállalkozóval hozatták, aki sümegi telephelyére márványt is szállít Olaszországból. A faj Csákánydoroszlóra kerülésének tehát ez is egy módja lehetett; továbbiként pedig felmerülhet a helyi temetőből való kiszökése is. A növény láthatóan erős vitalitással szövi át a szomszédos gyepet, terjedése határozottnak tűnik. Az élőhely állományfelvétele, 2016. május 29-én:

Kitettség: DK-D, Dőlés: 40ํ, Felvételi terület nagysága: $2 \times 2 \mathrm{~m}$, Borítás (\%): gyepszint: 95 : Phuopsis stylosa 20, Glechoma hederacea 20, Carex hirta 10, Lysimachia nummularia 10, Plantago lanceolata 10, Trifolium repens 10 , Elymus repens 5 , Festuca rubra 5, Poa pratensis 5 , Fallopia $\times$ bohemica + , Potentilla reptans + , Rumex sp. r, Összes fajszám: 12.

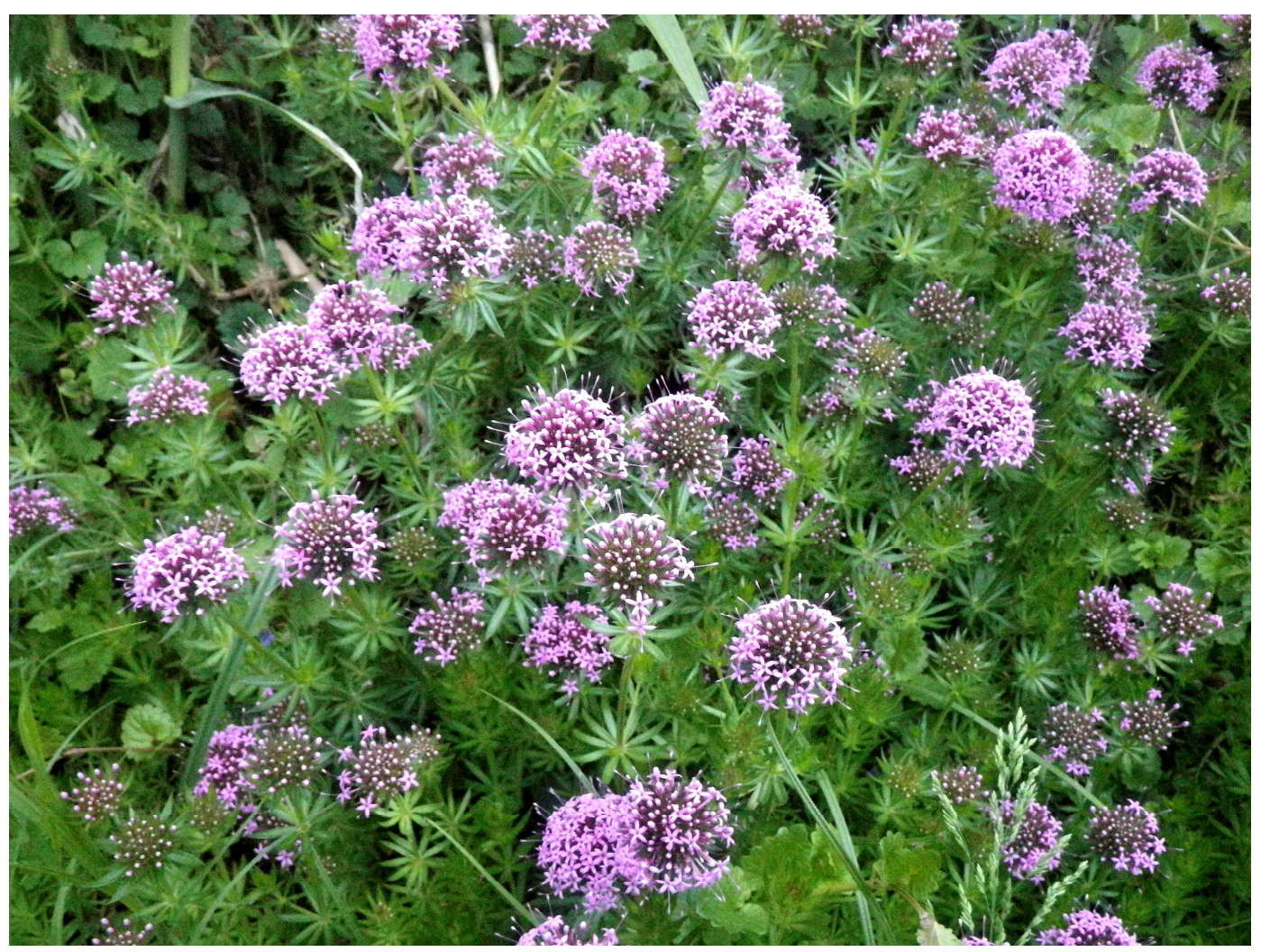

3. ábra. Phuopsis stylosa csákánydoroszlói lelőhelyén, 2016. május 16-án (Balogh Lajos felvétele)

Fig. 3. Phuopsis stylosa in Csákánydoroszló, Vas County, 16 May 2016 (photo by L. Balogh)

(A 2017. június 10-én felkeresett Ph. stylosa állomány az utóbbi években tapasztaltnál jóval keményebb telet követően is virul, sőt, terjedni látszik. BL) 
A Galium murale a budapesti Keleti pályaudvar egyik mellékvágánya mentén (koord.: N $47.295957^{\circ}, 19.051859^{\circ}$ ) került elő 2016. május 27-én (4. ábra). Az állomány egy kevésbé használt vágány szegélyében volt, közvetlenül a bazaltkövezés mellett, néhány $\mathrm{cm}$ átmérőjű kőmurván, sík felszínen. A szomszédos kerítés és a vágányon hosszabb ideje álló, nem üzemelő személykocsik miatt a nap nagy részében a növény árnyékban van, így a termőhely vízgazdálkodása a többi vágányénál kedvezőbb. A faj $2 \mathrm{~m}^{2}$-es foltban a megtalálás idején kezdett virágozni. A termőhelyen lévő vegetáció csak kevéssé záródott, ott az ásványi felszínek jellemző pionírjai és egyéves gyomjai (Vulpia myuros, Saxifraga tridactylites, Erophila verna, Diplotaxis tenuifolia, Erigeron annuus, Crepis tectorum, Eragrostis minor) voltak jelen. A Keleti pályaudvar napsütötte, szárazabb felszínű vasúti töltései mentén nem találtuk.

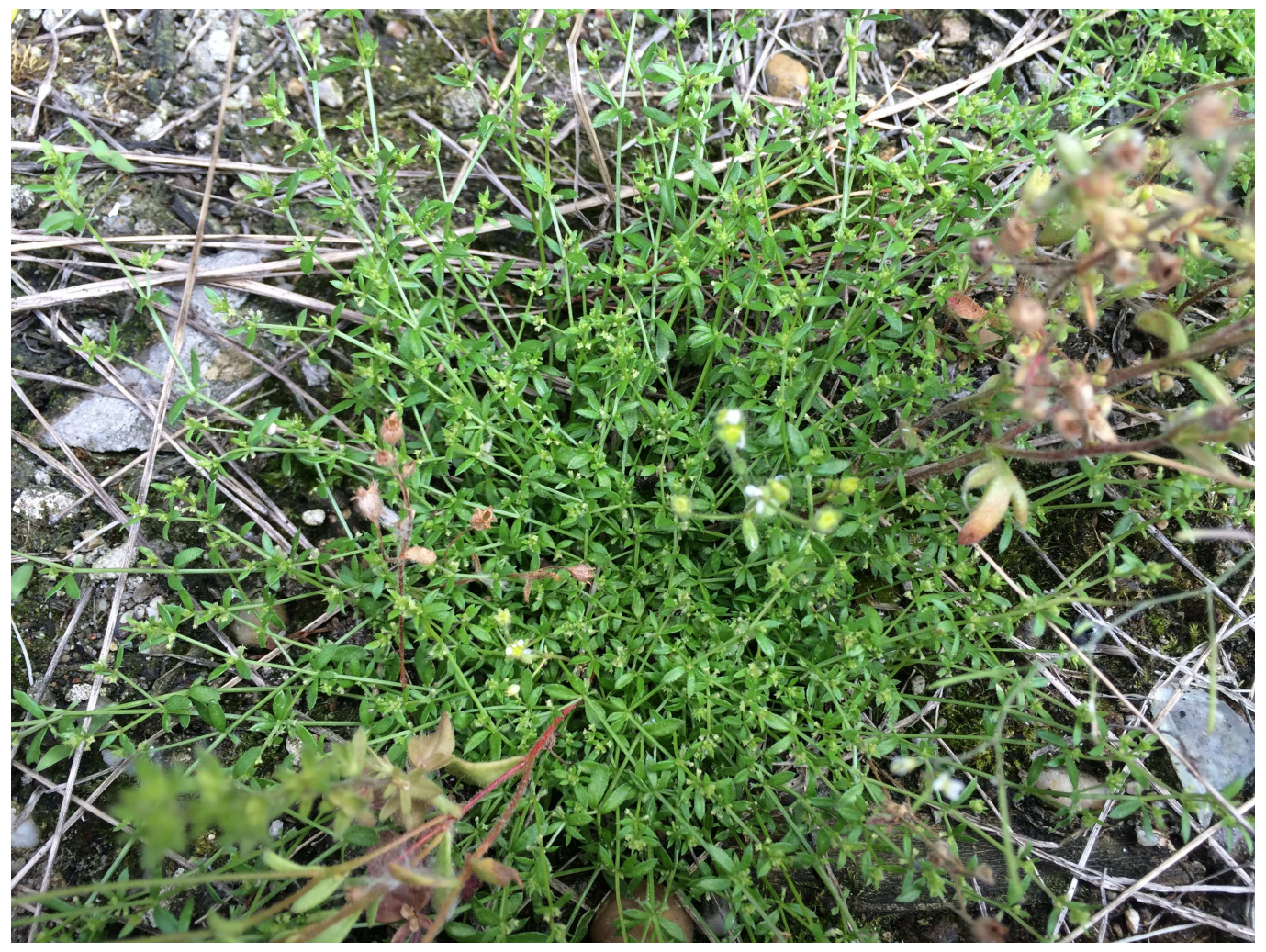

4. ábra. Galium murale Keleti pályaudvari lelőhelyén, 2016. május 27-én (Mesterházy Attila felvétele)

Fig. 4. Galium murale in Keleti railway station, Budapest, 27 May 2016 (photo by A. Mesterházy)

\section{Élőhelyi, ökológiai viszonyok}

A Phuopsis stylosa élőhelyei hazájában a hegyi rétek, erdőszélek és tisztások (LINCSEVSZKIJ 1961). Dísznövényként való alkalmazása esetén jól alkalmazható rézsűk, nagyobb sziklák, sziklakertek, talaj takarására, kerti évelőágyások szegélyezésére. A mínusz 15-18 ำ-ig fagytűrőnek tartott dísznövény ültetésére jó vízellátású, kevéssé kötött, sovány, homokos talajt, és napos vagy félárnyékos fekvést javasolnak. Szaporítása tavasszal tőosztással, nyáron félfás dugvánnyal, ősszel magvetéssel történik. Megfelelő körülmények között beérett magjait szétszórja (SILVA TAROUCA \& SCHNEIDER 1922, SCHRIKKER 1943, MACOBOY 1988, BRICKELL 1993, PARKER \& MALONE 2006). Figyelemre méltó, hogy a régebbi szakirodalmak rámutatnak 
hatékony terjedőképességére, megjegyezve, hogy e szép és tartós virítású dísznövény nyílt talajú kertekben gyakran elszaporodik, vagy benövi a többi dísznövényt (SILVA TAROUCA \& SCHNEIDER 1922, LINCSEVSZKIJ 1961).

A Galium murale őshonos elterjedési területein sziklás, köves, bolygatott helyeken, kőfalakon, útszéleken, járdaszegélyekben előforduló faj. Hasonló élóhelyeken jelenik meg adventívként is (EHRENDORFER et al. 1976, Hoste et al. 2009, PRANČL 2012, Verloove 2016).

\section{Következtetések}

A hazai jövevényflóra az itt közölt adatok alapján két újabb fajjal gyarapodott. Egy nálunk eddig igen ritkán alkalmazott, délnyugat-ázsiai származású dísznövény, a piros szálkanyak (Phuopsis stylosa) látványos elvadulása, féltermészetes gyepben való erőteljes terjedése az inváziós képesség tekintetében figyelemreméltó. Ez egybevág egy - kertészeti talajtakaró évelő lágyszárúak terjedőképességére vonatkozó - lengyelországi kísérlet eredményével, amelyben öt vizsgált faj közül ezé bizonyult a leghatékonyabbnak (DEBICZ \& BABELEWSKI 2010). Sajnos e tulajdonságát kihasználva próbálkoznak vele - a Brit-szigetek kezelt gyepterületeinek alternatív fenntartási módszereként - ún. „fümentes diverz gyepek” (valójában áldiverz, élő műgyepek) létrehozását célzó kísérletekben is (SMITH \& FELLOWES 2014). Mindezek is rávilágítanak a termesztési céllal behozni szándékozott növényfajokra vonatkozó kockázatelemzések szükségességére (BOTTA-DuKÁT \& SzIGETVÁRI 2007). A piros szálkanyakkal ellentétben a kőfali galaj (Galium murale) nem dísznövényként, hanem feltehetőleg a déli országokból (Horvátország, Görögország) jövő vasúti szerelvényekkel érkezett hozzánk. Hazánkban a kontinens déli részén élő növények közül a közelmúltban kimutatott adventív növények közül eddig csak a Geranium purpureum Vill. terjedése volt megfigyelhető a vasutak mentén (MESTERHÁZY 2006), de Szlovéniában, a határunktól nem túl messze, a maribori vasútállomáson korábban már az Aegilops triuncialis L. és a Chaenorrhinum litorale (Willd.) Rouy. is megjelent (KIRÁLY et al. 2007). A Galium murale most felfedezett kis állományának terjedési képessége egyelőre nem értékelhető, a megtelepedés státusza és a faj inváziós jellege csak a lelőhely több éven át tartó monitorozása alapján állapítható meg.

\section{Köszönetnyilvánítás}

A Phuopsis stylosa lelőhelyének területkezelésére vonatkozó tájékoztatást Horváth Istvánnak, Csákánydoroszló polgármesterének, a Szerbiára és Horvátországra vonatkozó adventívflorisztikai adatellenőrzésben nyújtott segítségét Goran Anačkovnak (University of Novi Sad, Újvidék, Szerbia) és Szabados Klárának (Tartományi Természetvédelmi Intézet, Újvidék, Szerbia), a hazai herbáriumokban való tájékozódás terén pedig Pifkó Dániel, Somlyay Lajos (BP, MTM Növénytár), Höhn Mária (Szent István Egyetem, Budapest), Juhász Magdolna (Kaposvári Egyetem), Sinigla Mónika (MTM Bakonyi Természettudományi Múzeuma, Zirc), Takács Attila (DE, Debreceni Egyetem) és Vojtkó András (EGR, Eszterházy Károly Egyetem, Eger) közremúködését köszönjük. A két növényfaj rajzainak elkészítéséért Jana Táborskának (Eszterházy Károly Egyetem, Eger) vagyunk hálásak.

\section{Irodalom}

ADEMA F. (1974): Aanwinsten voor de Nederlandse adventief-flora, 12. - Gorteria 6(7): 85-91.

BALOGH L. \& MESTERHÁzy A. (2017): Két új Rubiaceae-faj a hazai flórában: Phuopsis stylosa és Galium murale. In: Az MBT Botanikai Szakosztályának 1472. szakülése, Budapest, 2016. nov. 21. - Botanikai Közlemények 104(1): 174. 
BorBÁs V. (1893): Crucianella L. In: A Pallas Nagy Lexikona 4. kötet. - Budapest, p. 583.

BotTA-DukÁt Z. \& SzigETvÁRI Cs. (2007): 3.4.1. Kockázatelemző módszerek., 6.4. Függelék: Kockázatbecslési módszer az özönnövények értékelésére. In: CzúCZ B., KRöEL-DULAY GY., RÉDEI T., BоTTA-DuKát Z., MolNÁR Zs. (szerk.), Klímapolitika. Éghajlatváltozás és biológiai sokféleség. Elemzések az adaptációs stratégia tudományos megalapozásához. - Kutatási jelentés, MTA ÖBKI, Vácrátót, 2007. június, pp. 124, 203-211. http://klima.kvvm.hu/documents/14/NS termvd vgleges web.pdf (hozzáférés / accessed: 2016. XI. 10.)

BricKELl CH. (1993): Dísznövény enciklopédia. Az Angol Királyi Kertészeti Társaság kézikönyve. - Pannon Könyvkiadó, Budapest, 663 pp.

Clement E. J. \& Foster M. C. (1994): Alien Plants of the British Isles. - Botanical Society of the British Isles, London, $590 \mathrm{pp}$.

DebicZ R. \& BABELEWSKI P. (2010): Dynamika rozrastania się wybranych gatunków bylin na glebie ściółkowanej i nieściółkowanej korą sosnową. (Dynamics of the growth of some perennial ground cover in the soil mulched and not mulched with pine bark.) - Zeszyty Problemowe Postępów Nauk Rolniczych 551: 47-53.

DióSZEGI S. \& FAZEKAS M. (1807): Magyar füvész könyv. Melly a' két magyar hazábann találtatható növevényeknek megesmerésére vezet, a' Linné alkotmánya szerént. - Csáthy György, Debrecen, 608 pp.

Ehrendorfer F. (1976): Crucianella L. In: Tutin T. G., HeYwood V. H., Burges N. A., Moore D. M., Valentine D. H., Walters S. M. \& WebB D. A. (eds.): Flora Europaea. Volume 4. Plantaginaceae to Compositae (and Rubiaceae). - Cambridge University Press, Cambridge, pp. 3-4.

Ehrendorfer F., Krendl F. \& Puff Ch. (1976): Galium L. In: Tutin T. G., Heywood V. H., Burges N. A., Moore D. M., VAlentine D. H., Walters S. M. \& WebB D. A. (eds.): Flora Europaea. Volume 4. Plantaginaceae to Compositae (and Rubiaceae). - Cambridge University Press, Cambridge, pp. 14-36.

HAMBURGer I. (1948): Zur Adventivflora von Graz. Dissertation, Univ. Graz, Graz, 121 pp. (idézi Walter et al. 2002)

Hoste I., Verloove F., Nagels C., Andriessen L. \& LAmbinon J. (2009): De adventievenflora van in België ingevoerde mediterrane containerplanten. - Dumortiera 97: 1-16.

JAKucs P. (1981): A társulások felvételezése, a társulástabella készítése. In: HoRToBágYI T. \& Simon T. (szerk.), Növényföldrajz, társulástan és ökológia. - Tankönyvkiadó, Budapest, pp. 199-202.

JanChEn E. (1956-1960): Catalogus Florae Austriae. Bd. 1-4. Springer Verlag, Wien, 999 pp.

JÁVORKA S. (1924-1925): Magyar Flóra (Flora Hungarica). - Studium, Budapest, 1307 pp.

KAPLAN Z. \& ŘEноК̆EK V. (1998): Galium parisiense - a new alien species for the Czech Republic. - Preslia, Praha 70: 51-56.

KIRÁLY G. (szerk.) (2009): Új magyar füvészkönyv. Magyarország hajtásos növényei. Határozókulcsok. Aggteleki Nemzeti Park Igazgatóság, Jósvafő, 616 pp.

KirÁly G., Mesterházy A. \& BAKAn B. (2007): Elodea nuttalii (Planch.) H. St. John, Myosotis laxa Lehm. and Pyrus austriaca Kern., new for Slovenia, as well as other floristic records. - Hladnikia 20: 11-15.

KRAŠAN F. (1891): Bemerkungen über die Einbürgerung mehrerer ausländischer Pflanzenarten auf dem Grazer Schlossberg. - Mitt. Nat. Ver. St. 27: 229-230.

LincSEvszKi I. A. (1961): Phuopsis (Griseb.) Hook. f. In: KARJAGin I. I. (red.): Flora Azerbajdzsana, VIII. Rubiaceae-Compositae. - Izdatyelsztvo Akademii Nauk Azerbajdzsanszkoj SzSzR, Baku, pp. 12-14.

Maсовоч S. (1988): Stirling Macoboy's what flower is that? - Portland House, New York, 455 pp.

MESTERHÁzy A. (2006): Geranium purpureum Vill. előfordulása Magyarországon. - Kitaibelia 11(1): 65.

NAtAli A., MANEN J-F., Kienn M. \& EEhRENDORFER F. (1996): Tribal, generic and specific relationships in the Rubioideae-Rubieae (Rubiaceae) based on sequence data of a cpDNA intergene region. In: RoBBrecht E., PuFF C. \& SMETS E. (eds.), Proceedings of the 2nd International Rubiaceae Conference. Opera Botanica Belgica 7: 193-203.

PARKER J. \& MALONE M. (szerk.) (2006): Flóra. A világ legnagyobb kertészeti enciklopédiája. I-II. Athenaeum 2000 Kiadó, Budapest, 1584 pp.

PranČL J. (2012): Galium murale. In: HAdinec J. \& LuSTYK P. (eds.): Additamenta ad floram Reipublicae Bohemicae. X. - Zpr. Čes. Bot. Společ. 47(1): 47.

PRISZTER SZ. (1985): A magyar flóra és vegetáció rendszertani-növényföldrajzi kézikönyve VII. Kiegészítések és mutatók az I-VI. kötethez. - Akadémiai Kiadó, Budapest, 683 pp.

PRISZTER Sz. (1998): Növényneveink. A magyar és a tudományos növénynevek szótára. - Mezőgazda Kiadó, Budapest, 549 pp.

SCHRiKKer S. (1943): Schrikker Sándor faiskolájának árjegyzéke. A Magyar Faiskolai Szövetség tagja. - 
Alsótekerespuszta, 144 pp.

Silva Tarouca E. G. \& SchneIder C. (1922): Kulturhandbücher für Gartenfreunde. Erster Band. Unsere Freiland-Stauden. - Hölder-Pichler-Tempsky A. G. und G. Freytag GMBH, Wien - Leipzig, 418 pp.

Smith L. S. \& Fellowes M. D. E. (2014): The grass-free lawn: Management and species choice for optimum ground cover and plant diversity. - Urban Forestry \& Urban Greening 13(3): 433-442.

Soó R. (1966): A magyar flóra és vegetáció rendszertani-növényföldrajzi kézikönyve. Synopsis systematico-geobotanica florae vegetationisque Hungariae. II. - Akadémiai Kiadó, Budapest, 655 pp.

Stace C. (eds.) (2010): New Flora of the British Isles. Third edition. - Cambridge University Press, Cambridge, xxxiv + $1232 \mathrm{pp}$.

Tutin T. G., Heywood V. H., Burges N. A., Moore D. M., Valentine D. H., Walters S. M. \& WebB D. A. (eds.) (1976): Flora Europaea. Volume 4. Plantaginaceae to Compositae (and Rubiaceae). - Cambridge University Press, Cambridge, 505 pp. + V maps.

VIDÉKI R. (2009): Rubiaceae - Galajfélék (buzérfélék) családja. In: KiRÁLY G. (szerk.): Új magyar füvészkönyv. Magyarország hajtásos növényei. Határozókulcsok. - Aggteleki Nemzeti Park Igazgatóság, Jósvafo, pp. 387-393.

Walter J., Essl F., Niklfeld H., Fischer M. A., Eichberger Ch., Englisch Th., Grims F., Hohla M., Melzer H., PIlsL P. \& STÖHR O. (2002): Gefäßpflanzen. In: EssL F. \& RABITSCH W. (eds.): Neobiota in Österreich. Umweltbundesamt, Wien, pp. 46-173.

WEISS-SCHNEEWEISS H. \& SCHNEEWEISS G. M. (2003): Karyological investigations of selected angiosperms From Georgia and Azerbaijan. - Acta Biologica Cracoviensia Series Botanica 45(2): 49-56.

\section{Világhálóhelyek}

MBG (2017): Missouri Botanical Garden [website]. - St. Louis, MO, USA. http://www.missouribotanicalgarden.org (hozzáférés / accessed: 2017. V. 7.)

RBG (2016): The Plant List: Phuopsis stylosa (Trin.) Hook.f. ex B.D.Jacks. - Royal Botanic Gardens, Kew and Missouri Botanic Garden. 2013. Retrieved 19 June 2016. http://www.theplantlist.org/tpl1.1/record/kew-153202 (hozzáférés / accessed: 2016. IX. 8.)

THIERS B. (2017) [continuously updated]: Index Herbariorum. A global directory of public herbaria and associated staff. New York Botanical Garden's Virtual Herbarium. http://sweetgum.nybg.org/science/ih/ (hozzáférés / accessed: 2017. V. 3.)

VerLoove F. (2016): [Galium murale]. In: Manual of the Alien Plants of Belgium. - Botanic Garden of Meise, Belgium, http://alienplantsbelgium.be (hozzáférés / accessed: 2016. IX. 15.)

WPF (2016): World checklist of selected Plant Families. http://apps.kew.org/wcsp/namedetail.do?name_id=86930 (hozzáférés / accessed: 2016. IX. 15.)

Beérkezett: 2016. 11.11. • Elfogadva: 2017.05. 09. 